\title{
The effects of cohousing model on people's health and wellbeing: a scoping review
}

Juli Carrere ${ }^{1,2,3^{*}}$ (D) Alexia Reyes ${ }^{1,3}$, Laura Oliveras ${ }^{1,2,3}$, Anna Fernández ${ }^{1,4}$, Andrés Peralta ${ }^{1}$, Ana M. Novoa ${ }^{1}$, Katherine Pérez ${ }^{1,2,4}$ and Carme Borrell ${ }^{1,2,3,4}$

* Correspondence: julicarrere@ gmail.com

${ }^{1}$ Agència de Salut Pública de Barcelona, PI. Lesseps 1, 08023 Barcelona, Spain

${ }^{2}$ Institut d'Investigació Biomèdica (IIB Sant Pau), C. Sant Quintí 77, 08041 Barcelona, Spain

Full list of author information is available at the end of the article

\begin{abstract}
Background: Housing is a social determinant of health. Extensive research has highlighted its adverse effects on health. However, less is known about the effects of cohousing typology on health, which has the potential to create lively social networks and healthy communities and environments. We report the findings of a scoping study designed to gather and synthesise all known evidence on the relationship between cohousing and wellbeing and health.
\end{abstract}

Method: Using the scoping review method, we conducted a literature review in PubMed, ProQuest, Scopus, Web of Science, Science Direct and JSTOR in May 2019 and selected articles published from 1960 onwards, with no geographical limit and no design restrictions. Retrieved articles underwent three sequential screening phases. The results were described through a narrative synthesis of the evidence.

Results: Of the 2560 articles identified, we selected 25 full-text articles analysing 77 experiences. All of them were conducted in high-income countries. Ten studies analysed the impact of cohousing on physical and mental health or quality of life and wellbeing. Eight of the 10 studies found a positive association. In addition, 22 studies analysed one or more psychosocial determinants of health (such as social support, sense of community and physical, emotional and economic security) and most found a positive association. Through these determinants, quality of life, wellbeing and health could be improved. However, the quality of the evidence was low.

Discussion: The cohousing model could enhance health and wellbeing mediated by psychosocial determinants of health. However, extreme caution should be exercised in drawing any conclusions due to the dearth of data identified and the designs used in the included studies, with most being cross-sectional or qualitative studies, which precluded causal-based interpretations. Because housing is a major social determinant of health, more evidence is needed on the impact of this model on health through both psychosocial and material pathways.

Keywords: Cohousing, Health, Wellbeing, Quality of life, Psychosocial determinants of health, Scoping review

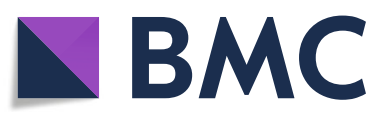

(c) The Author(s). 2020 Open Access This article is licensed under a Creative Commons Attribution 4.0 International License, which permits use, sharing, adaptation, distribution and reproduction in any medium or format, as long as you give appropriate credit to the original author(s) and the source, provide a link to the Creative Commons licence, and indicate if changes were made. The images or other third party material in this article are included in the article's Creative Commons licence, unless indicated otherwise in a credit line to the material. If material is not included in the article's Creative Commons licence and your intended use is not permitted by statutory regulation or exceeds the permitted use, you will need to obtain permission directly from the copyright holder. To view a copy of this licence, visit http://creativecommons.org/licenses/by/4.0/. The Creative Commons Public Domain Dedication waiver (http://creativecommons.org/publicdomain/zero/1.0/) applies to the data made available in this article, unless otherwise stated in a credit line to the data. 


\section{Background}

Housing is widely recognised as a social determinant of health $[1,2]$. Health outcomes are affected by housing affordability, stability, quality and the emotional link to housing, along with the physical and social characteristics of neighbourhoods [3, 4]. While the evidence for the adverse effects of housing on physical and mental health has been reviewed $[2,3,5,6]$, there has been little assessment of the beneficial health effects of housing arrangements where people intentionally live together in a community. Evidence suggests that communal living arrangements reduce feelings of loneliness and increase perceived wellbeing among the senior population compared with residents living in single arrangements $[7,8]$.

Among communal living arrangements, here we review the cohousing model. The existing literature on cohousing is characterised by a certain degree of ambiguity and overlap between different terms and experiences. However, there is consensus among different authors in defining cohousing as a form of community living that contains a mix of private and communal spaces with substantial self-managed common facilities and activities aimed at everyday living [9-11].

To date, the evidence suggests that cohousing decreases isolation in seniors, positively impacts inhabitants' quality of life and benefits physical and mental health [12, 13]. Among intergenerational housing residents, cohousing also increased mutual support and created a sense of community among residents [14-16]. These feelings could be extended to the neighbourhood by increasing the sense of community beyond the boundaries of cohousing, resulting in improved wellbeing among residents [17]. However, there are fewer studies on the physical and mental health effects in intergenerational populations, and the results appear unclear.

The cohousing model was created in Denmark in the early 1970s as an innovative form of collective housing and later spread to other northern European countries, the USA [18] and other latitudes such as Uruguay [19]. In recent years, cohousing has re-emerged in the USA, Europe, Australia, New Zealand and Japan [16, 20, 21]. This re-emergence has been associated with a growing desire for a sense of belonging, to experience more connection with the community and an increasing rejection of dominant consumption patterns [22]. In addition, it has been boosted by the lack of affordable housing and poor rental conditions and has been presented as a potential alternative to conventional tenure arrangements $[16,18,23]$. Research on the cohousing model has so far covered different topics. For example, the architectural features and physical layout of buildings [15, 24, 25], the environmental sustainability practices in communities [26-29] and self-management and decision processes [30]. Few studies, however, have explored the different tenure modalities [23, 31], their ability to promote social capital [16] and whether social housing could be an opportunity for municipalities to promote socially inclusive urban development [32].

The cohousing model has also attracted the attention of public health [33]. The driving motivation is to provide evidence of the increased quality of life among people living in cohousing, which is often an objective of cohousing projects but is rarely assessed, to facilitate evidence-based decision-making. From the point of view of health promotion, the expansion of this model is related to the need to respond to the phenomenon of social isolation through community-based housing models that promote healthy built environments and foster people's social cohesion [33]. Furthermore, the cohousing model is credited with the ability to improve the affordability of housing [18], which is known to be beneficial to the wellbeing of the population. 
Although there is only a modest number of studies on cohousing and health, wellbeing, or quality of life, research in this field is slowly increasing. The present review aims to gather and synthesise all the known evidence on the relationship between cohousing and health and wellbeing.

\section{Methods}

We conducted a literature review using the scoping review method. This method has an exploratory character and is indicated to synthesise the scientific knowledge and identify the key concepts and research gaps in areas of study with little available scientific evidence [34]. The literature search was performed in May 2019, and we consulted databases in social sciences, architecture and health: PubMed, ProQuest, Scopus, Web of Science, Science Direct and JSTOR. Full details of the search strings used for the various databases are shown in Supplementary 1. Note that to capture articles related to cohousing and health, the search syntax was adapted to each database.

The inclusion criteria were peer-reviewed documents: (1) studies of cohousing living arrangements where communal spaces and/or common facilities or services are available and self-managed; (2) documents published after 1960, as the cohousing model started in Denmark in the 1960s; (3) documents that analysed at least one health outcome such as physical or mental health, self-perceived health, or wellbeing, or assessed psychosocial determinants of health, such as social support, social isolation, life satisfaction, happiness, or sense of community; and (4) documents written in English, Spanish, French, German or Italian. We excluded books and conference communications and studies without an available summary.

We applied three sequential phases of document screening to the list of documents retrieved by the searches. In phases 1 and 2, we screened the documents by title/abstract and full text, respectively. In phase 3, we manually retrieved additional documents that also met the inclusion criteria from the reference lists of the documents selected, as well as the literature identified after expert consultation and repeated the same screening procedure. Details of the experts contacted are shown in Supplementary 2. To ensure internal validity, we triangulated the results as follows: phases 1 and 2 were carried out separately by three independent pairs of researchers, who discussed the inclusion/exclusion of the documents that generated doubts. A third researcher was included if there were still doubts. For the articles retrieved in phase 3, we replicated the same selection and triangulation process, but only one pair of researchers participated.

For each selected document, we extracted the following information: (a) characteristics of the studies, (b) characteristics of cohousing projects studied and (c) healthrelated outcomes. The included characteristics of the studies were year of publication, type of methods and number of projects studied. The characteristics of cohousing projects were year of cohousing project creation, country of cohousing project, age target and co-ownership tenure. The health-related outcomes analysed were grouped in (i) self-perceived physical and mental health, (ii) quality of life and wellbeing and (iii) psychosocial determinants of health, which include social support, social isolation, sense of community and sense of security and safety.

Finally, we provide an in-depth description of the main health-related findings of cohousing projects studied. 


\section{Results}

The search and selection process and the documents included are summarised in Fig. 1. The search resulted in a total of 2983 documents: 516 in PubMed, 31 in ProQuest, 913 in Scopus, 922 in the Web of Science, 93 in Science Direct and 508 in JSTOR. Of these, 269 were duplicates. In all, 2291 documents were excluded after reviewing the title and abstract. After reading the full text of the remaining 137 documents, 24 were included. We reviewed the references from these documents, and we contacted experts by e-mail. Eight experts offered information or referred us to other experts or specialised organisations. As a result, 41 new documents were retrieved, and 1 was selected for the review. A total of 25 documents were finally included in the scoping review.

Table 1 shows the main characteristics of the documents selected. The publication rate tended to increase over time, with $24 \%$ of the documents published between 2001 and 2010, and $64 \%$ of documents published after 2010. Regarding the study designs, $20 \%$ were quantitative studies, all were cross-sectional and two of them had a comparison group. A total of $40 \%$ were qualitative studies, and the most commonly used techniques were in-depth interviews $(n=6)$ and semi-structured interviews $(n=4)$, while four studies applied more than one technique. Mixed methods were employed by $40 \%$ of the studies. Three of them used longitudinal designs. Two studies used a comparison group in the quantitative approach, while in-depth interview was the most commonly applied technique in the qualitative approach.

The proportion of articles examining between two and five cohousing living arrangements projects per document was high (44\%). The 25 studies examined a total of 77

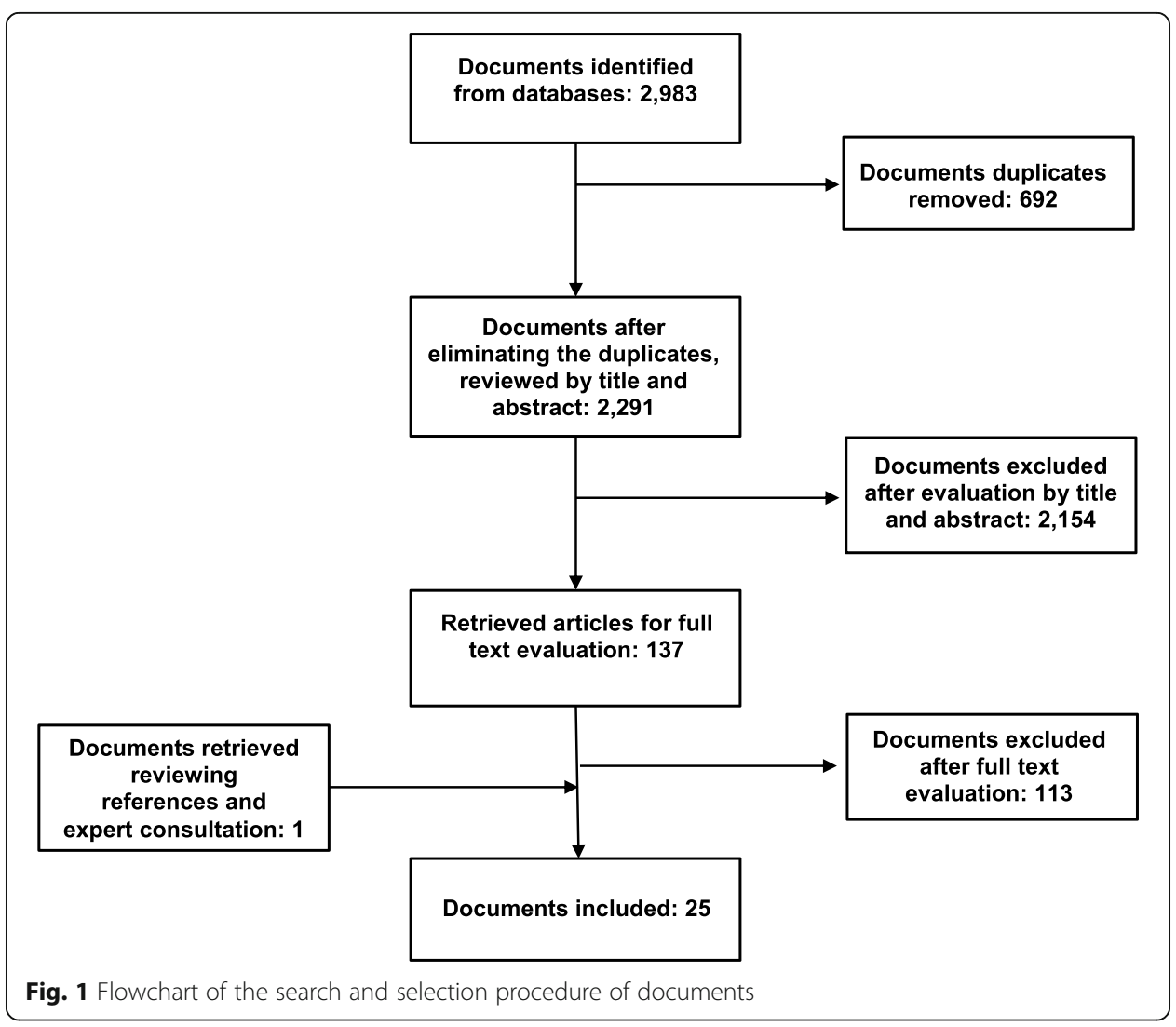


Table 1 Description of studies included by year of publication, country, methods and number of cohousing projects studied, as well as description of cohousing projects by year of creation, country, age target and co-ownership status dimension and the health outcomes analysed

\begin{tabular}{lll}
\hline & $\mathbf{N}$ & (\%) \\
\hline a) Characteristics of the studies & 25 & 100.0 \\
Year of publication & & \\
Before 1990 & 0 & 0.0 \\
$1990-2000$ & 3 & 12.0 \\
$2001-2010$ & 6 & 24.0 \\
After 2010 & 16 & 64.0
\end{tabular}

\section{Methods}

Quantitative

- Cross-sectional with comparison group

- Cross-sectional without comparison group

Qualitative*

- In-depth interviews

- Semi-structured interviews

- Group discussion

- Participant observation

Mixed methods

- Quantitative

- Longitudinal without comparison group 3

- Cross-sectional with comparison group 2

- Cross-sectional without comparison group 5

- Qualitative**

- Longitudinal in-depth interviews 3

- In-depth interviews 4

- Semi-structured interviews 3

- Group discussion 1

- Participant observation 1

Number of projects included per document

1

$2-5$

$+5$

b) Characteristics of cohousing projects studied

Year of cohousing projects creation

$\begin{array}{lll}\text { Before } 1990 & 19 & 25.0 \\ 1990-2000 & 17 & 22.0 \\ 2001-2010 & 30 & 39.0 \\ \text { After } 2010 & 4 & 5.0 \\ \text { Unknown } & 7^{*} & 9.0\end{array}$

Country of cohousing projects

$\begin{array}{lcc}\text { Canada } & 18 & 23.0 \\ \text { Europe } & 41 & 53.0 \\ \text { USA } & 18 & 23.0\end{array}$


Table 1 Description of studies included by year of publication, country, methods and number of cohousing projects studied, as well as description of cohousing projects by year of creation, country, age target and co-ownership status dimension and the health outcomes analysed (Continued)

\begin{tabular}{lll}
\hline & N & (\%) \\
\hline Intergenerational & 48 & 62.0 \\
Elderly & 29 & 38.0
\end{tabular}

\section{Co-ownership tenure}

No

Yes

c) Health related outcomes***

$27 \quad 35.0$

Self-perceived physical and mental health

$25 \quad 100.00$

Quality of life and well-being

416.0

Psychosocial determinants of health

-Social support

- Social isolation

-Sense of community

d) Effects of cohousing on the health outcomes analysed

Self-perceived physical and mental health

- Beneficial

- Neutral

- Detrimental

Total****

Quality of life and well-being

- Beneficial

- Neutral

- Detrimental

Total

Psychosocial determinants of health

- Beneficial

- Neutral

- Detrimental

Total****

*Four studies used more than one qualitative research technique

**Two studies used more than one qualitative research technique

***Several studies considered more than one type of health-related outcomes; the percentage corresponds to the number of studies in which the health outcome was analysed

****Several studies reported more than one type of health-related outcomes; furthermore, three studies reported different health effects on the same health outcome because they analysed different subpopulations or different indicators

projects. A quarter (25\%) of the cohousing projects studied were created before 1990, 22\% between 1990 and 2000, 39\% between 2001 and 2010 and only 5\% after 2010. Most projects (53\%) were conducted in European countries, with the vast majority being conducted in northern countries, followed by the USA (23\%) and Canada (23\%). Cohousing projects target predominantly the intergenerational population $(62 \%)$, and tenure was co-ownership (35\%).

Regarding health outcomes, four studies analysed physical and mental health through self-perceived assessment, and one of them measured healthcare requirements. Six studies analysed quality of life and wellbeing. Twenty-two selected studies included the 
psychosocial determinants of health. Finally, beneficial effects of cohousing on health outcomes were reported in three studies analysing physical and mental health, in five analysing quality of life and wellbeing and in twenty assessing psychosocial determinants of health.

\section{Cohousing-related health effects}

Table 2 describes the health outcomes and the psychosocial determinants of health of the cohousing projects studied, and Table 3 summarises their observed effects.

\section{Self-perceived physical and mental health}

Four studies aimed to assess the impact of cohousing on self-perceived physical and mental health. Two of them used mixed methods [35, 36], one used quantitative method [37] and the other applied a qualitative design [38]. The former did not provide the guide used in the interviews. The three studies employing survey-based quantitative approaches used a validated question-self-perceived health-and no other scales. Mental health was assessed one-dimensionally, with no scales measuring more than one mental health domain.

Self-perceived physical and mental health in two senior projects increased in the followup $[35,36]$, while in the intergenerational projects the effect on health was less clear. No significant differences were observed in self-perceived physical health in the single article that used a comparison group, although cohousing residents reported less need for health and social care services [37]. In contrast, a project for low-income middle-aged women found that residents reported a deterioration in their physical and mental health after they moved to the cohousing cooperative [38].

\section{Quality of life and wellbeing}

All but one study assessing quality of life and wellbeing reported positive benefits for cohousing residents, two using qualitative methods [39-41], one mixed method [42] and another one quantitative method [43]. The single study that did not report significant benefits used a quantitative method with a comparison group [44]. The latter compared cohousing residents who were owners with residents in congregated apartments who were tenants. Only one study using a qualitative approach provided information on the interview guide used [39]. Two of the studies employing quantitative approaches provided information on the questions used to assess quality of life [43, 44]; none of the studies used the same scale.

The studies that found improvements in quality of life and wellbeing explained these gains by increased autonomy, increased opportunities to participate in the community and greater solidarity among cohousing residents, in both senior [39-41] and intergenerational $[42,43]$ projects. One of these intergenerational projects was based on Canadian non-profit cohousing cooperatives for people with functional diversity [42]. In this case, improvements in the quality of life of the residents were more related to the ability to decide how to live individually and socially than to the ability to control the physical environment.

\section{Psychosocial determinants of health}

\section{Social support}

Social support was assessed through seven studies using a mixed methods design $[12,35,45-49]$, including two with a comparison group $[14,50]$, nine qualitative 
Table 2 Description of the main health-related results found in the cohousing projects

\begin{tabular}{|c|c|c|c|c|c|}
\hline $\begin{array}{l}\text { 1st Author, } \\
\text { year }\end{array}$ & Aim & $\begin{array}{l}\text { Characteristics } \\
\text { of the projects }\end{array}$ & $\begin{array}{l}\text { Methodology } \\
\text { (design or } \\
\text { technique) }\end{array}$ & Instruments & Main results \\
\hline $\begin{array}{l}\text { Altus and } \\
\text { Mathews, } 2002\end{array}$ & $\begin{array}{l}\text { To compare the } \\
\text { satisfaction of } \\
\text { rural senior } \\
\text { housing } \\
\text { cooperative and } \\
\text { rental apartments } \\
\text { members. }\end{array}$ & $\begin{array}{l}\text { Cohousing } \\
\text { country: USA } \\
\text { Age target: } \\
\text { Elderly } \\
\text { Co-ownership: } \\
\text { Yes }\end{array}$ & $\begin{array}{l}\begin{array}{l}\text { Quantitative } \\
\text { (cross-sectional }\end{array} \\
\text { with comparison } \\
\text { group) } \\
\mathbf{N}: 39 \\
\text { cooperative } \\
\text { residents; } 48 \\
\text { rental } \\
\text { apartments } \\
\text { Number of } \\
\text { projects } \\
\text { studied: } 3\end{array}$ & $\begin{array}{l}\text { Quality of life } \\
\text { measured by } \\
\text { well-being index } \\
\text { with } 12 \text { items re- } \\
\text { lated to safety, } \\
\text { happiness, life } \\
\text { satisfaction, } \\
\text { friends, physical } \\
\text { health, and psy- } \\
\text { chological } \\
\text { health. }\end{array}$ & $\begin{array}{l}\text { QUALITY OF } \\
\text { LIFE AND WELL- } \\
\text { BEING } \\
\text { There are no } \\
\text { significant } \\
\text { differences } \\
\text { between } \\
\text { cohousing } \\
\text { cooperative } \\
\text { residents and } \\
\text { rental apartment } \\
\text { residents. }\end{array}$ \\
\hline Bamford, 2005 & $\begin{array}{l}\text { To explore the } \\
\text { physical } \\
\text { structures and } \\
\text { experiences of } \\
\text { older people } \\
\text { living in } \\
\text { cohousing. }\end{array}$ & $\begin{array}{l}\text { Cohousing } \\
\text { country: } \\
\text { Denmark and } \\
\text { Netherlands } \\
\text { Age target: } \\
\text { Elderly } \\
\text { Co-ownership: } \\
\text { Yes }\end{array}$ & $\begin{array}{l}\text { Qualitative } \\
\text { (cross-sectional; } \\
\text { in-depth } \\
\text { interviews) } \\
\mathbf{N} \text { : unknown } \\
\text { Number of } \\
\text { projects } \\
\text { studied: } 2\end{array}$ & $\begin{array}{l}\text { Interview guide } \\
\text { not provided. }\end{array}$ & $\begin{array}{l}\text { PSYCHOSOCIAL } \\
\text { DETERMINANTS } \\
\text { OF HEALTH } \\
\text { Social support: } \\
\text { Physical } \\
\text { structures } \\
\text { facilitate social } \\
\text { relations and } \\
\text { benefit the sense } \\
\text { of security. } \\
\text { Different people } \\
\text { go on outings } \\
\text { together and in } \\
\text { general } \\
\text { "appreciate the } \\
\text { social contact" } \\
\text { and the } \\
\text { possibility of } \\
\text { "help or } \\
\text { assistance" in } \\
\text { time of need, but } \\
\text { they remain keen } \\
\text { to preserve their } \\
\text { autonomy. }\end{array}$ \\
\hline $\begin{array}{l}\text { Choi and } \\
\text { Paulsson, } 2011\end{array}$ & $\begin{array}{l}\text { To evaluate the } \\
\text { social support } \\
\text { and quality of life } \\
\text { in Swedish } \\
\text { cohousing units. }\end{array}$ & $\begin{array}{l}\text { Cohousing } \\
\text { country: Sweden } \\
\text { Age target: } \\
\text { Intergenerational } \\
\text { Co-ownership: } \\
\text { No }\end{array}$ & $\begin{array}{l}\text { Quantitative } \\
\text { (cross-sectional } \\
\text { without } \\
\text { comparison } \\
\text { group) } \\
\mathrm{N}: 241 \\
\text { Number of } \\
\text { projects } \\
\text { studied: } 12\end{array}$ & $\begin{array}{l}\text { Life satisfaction } \\
\text { with housing } \\
\text { was measured by } \\
6 \text { items with } \\
\text { Likert-scale of } 3 \\
\text { points and } 5 \\
\text { points. }\end{array}$ & $\begin{array}{l}\text { QUALITY OF } \\
\text { LIFE AND WELL- } \\
\text { BEING } \\
\text { Increase life } \\
\text { satisfaction } \\
\text { among people } \\
\text { living in } \\
\text { cohousing } \\
\text { compared to } \\
\text { their own } \\
\text { experience } \\
\text { before and after } \\
\text { moving. } \\
\text { Most } \\
\text { respondents } \\
\text { indicated high } \\
\text { level of } \\
\text { satisfaction and } \\
\text { happiness with } \\
\text { their lives in } \\
\text { cohousing. } \\
\text { People over } 60 \\
\text { thought they } \\
\text { lived better than } \\
\text { others of their } \\
\text { age living in } \\
\text { conventional } \\
\text { housing. } \\
\text { Pcyryscoral }\end{array}$ \\
\hline
\end{tabular}

PSYCHOSOCIAL 
Table 2 Description of the main health-related results found in the cohousing projects (Continued)

\begin{tabular}{ll}
\hline $\begin{array}{l}\text { 1st Author, } \\
\text { year }\end{array}$ & Aim \\
\hline & \\
& \\
& \\
Cooper and & $\begin{array}{l}\text { To assess how } \\
\text { differences in } \\
\text { physical design } \\
\text { and the ability of } \\
\text { residents to } \\
\text { control the } \\
\text { environment } \\
\text { affect their } \\
\text { quality of life. }\end{array}$
\end{tabular}

Characteristics of the projects

Methodology Instruments Main results
(design or
technique)

DETERMINANTS

OF HEALTH

Social support:

mutual support

in cohousing

communities is

perceived greater

than in

conventional

ones.

Cohousing
country: Canada
Age target:
Intergenerational
Co-ownership:
Yes

Mixed methods Quantitative:

QUALITY OF LIFE AND WELLBEING cross-sectional conducted to gather data on levels of satisfaction, quality of life, group) Qualitative (cross-sectional: in-depth participation, control, and interviews) $\mathrm{N}: 62$ with social integration. Qualitative: interview guide disabilities; 241 without disabilities

Number of projects studied: 16

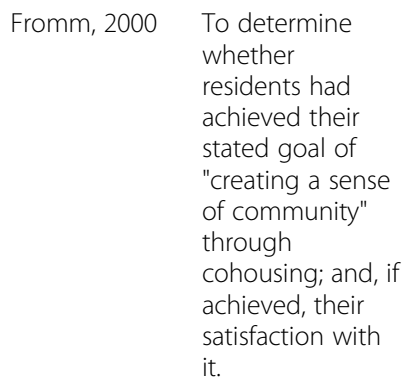

\section{Cohousing \\ Mixed methods} country: USA

Age target:

Intergenerational Co-ownership: No

Quantitative

(cross-sectional

without

comparison

group

Qualitative

(cross-sectional

semi-structured

interviews)

$\mathbf{N}$ :85 units

Number of

projects

studied: 3

neighbours to
To describe a residentmanaged elderonly cohousing

\author{
Cohousing \\ country: USA \\ Age target: \\ Elderly
}

Mixed method

Quantitative (longitudinal without
The social control perceived by

residents over their residential environment was more important

than their perceived physical control (accessibility) in explaining the perceived quality of life.

PSYCHOSOCIAL DETERMINANTS OF HEALTH Social support:

$100 \%$ of

cohousing

residents would

feel comfortable

asking

help with tasks

or errands if they were ill, in their

previous conventional housing only $40 \%$ reported the same possibility. Sense of community: The residents have a much stronger sense of community within cohousing than in their previous neighbourhood. Sense of security: There are feelings of security within the cohousing community.

SELF-PERCEIVED

PHYSICAL AND MENTAL HEAL

TH 
Table 2 Description of the main health-related results found in the cohousing projects (Continued)

\begin{tabular}{|c|c|c|c|c|c|}
\hline $\begin{array}{l}\text { 1st Author, } \\
\text { year }\end{array}$ & Aim & $\begin{array}{l}\text { Characteristics } \\
\text { of the projects }\end{array}$ & $\begin{array}{l}\text { Methodology } \\
\text { (design or } \\
\text { technique) }\end{array}$ & Instruments & Main results \\
\hline & $\begin{array}{l}\text { community fo- } \\
\text { cusing on mutual } \\
\text { support and af- } \\
\text { fordable housing. }\end{array}$ & $\begin{array}{l}\text { Co-ownership: } \\
\text { No }\end{array}$ & $\begin{array}{l}\text { comparison } \\
\text { group) } \\
\text { Qualitative } \\
\text { (longitudinal; in- } \\
\text { depth } \\
\text { interviews) } \\
\mathrm{N}: 33 \\
\text { Number of } \\
\text { projects } \\
\text { studied: } 1\end{array}$ & $\begin{array}{l}\text { self-perceived } \\
\text { physical health } \\
\text { and self- } \\
\text { perceived mental } \\
\text { health. } \\
\text { Qualitative: } \\
\text { interview guide } \\
\text { not provided. }\end{array}$ & $\begin{array}{l}\text { 19\% of project } \\
\text { participants } \\
\text { report } \\
\text { improvements } \\
\text { and 13\% } \\
\text { reported } \\
\text { worsening in } \\
\text { physical health } \\
\text { compared to one } \\
\text { year ago. } \\
\text { 28\% reported } \\
\text { improvements in } \\
\text { mental health } \\
\text { and 3\% reported } \\
\text { worsening } \\
\text { mental health. } \\
\text { PSYCHOSOCIAL } \\
\text { DETERMINANTS } \\
\text { OF HEALTH } \\
\text { Social support: } \\
\text { Residents count } \\
\text { on their } \\
\text { neighbours for } \\
\text { help with } \\
\text { household and } \\
\text { personal care. } \\
\text { Sense of } \\
\text { community: The } \\
\text { sense of } \\
\text { community and } \\
\text { mutual support } \\
\text { are perceived as } \\
\text { important } \\
\text { reasons for living } \\
\text { in a cohousing. }\end{array}$ \\
\hline Glass, 2012 & $\begin{array}{l}\text { To describe the } \\
\text { health status of } \\
\text { three elder- } \\
\text { cohousing } \\
\text { projects. }\end{array}$ & $\begin{array}{l}\text { Cohousing } \\
\text { country: USA } \\
\text { Age target: } \\
\text { Elderly } \\
\text { Co-ownership: } \\
\text { No }\end{array}$ & $\begin{array}{l}\text { Mixed methods } \\
\text { Quantitative } \\
\text { (longitudinal } \\
\text { without } \\
\text { comparison } \\
\text { group) } \\
\text { Qualitative } \\
\text { (longitudinal; in- } \\
\text { depth } \\
\text { interviews) } \\
\mathrm{N}: 58 \\
\text { Number of } \\
\text { projects } \\
\text { studied: } 3\end{array}$ & $\begin{array}{l}\text { Quantitative: } \\
\text { General health } \\
\text { was measured by } \\
\text { self-perceived } \\
\text { health. } \\
\text { Information on } \\
\text { mental health } \\
\text { scale used not } \\
\text { provided. } \\
\text { Qualitative: } \\
\text { interview guide } \\
\text { not provided. }\end{array}$ & $\begin{array}{l}\text { SELF-PERCEIVED } \\
\text { PHYSICAL AND } \\
\text { MENTAL HEAL } \\
\text { TH } \\
\text { The majority had } \\
\text { good physical } \\
\text { and mental } \\
\text { health and it } \\
\text { remained the } \\
\text { same a year later } \\
\text { living in the } \\
\text { cohousing }\end{array}$ \\
\hline Glass, 2013 & $\begin{array}{l}\text { To evaluate how } \\
\text { cohousing } \\
\text { projects, } \\
\text { influence the } \\
\text { ageing of older } \\
\text { people. }\end{array}$ & $\begin{array}{l}\text { Cohousing } \\
\text { country: USA } \\
\text { Age target: } \\
\text { Elderly } \\
\text { Co-ownership: } \\
\text { No }\end{array}$ & $\begin{array}{l}\text { Mixed methods } \\
\text { Quantitative } \\
\text { (longitudinal } \\
\text { without } \\
\text { comparison } \\
\text { group) } \\
\text { Qualitative } \\
\text { (longitudinal } \\
\text { without } \\
\text { comparison } \\
\text { group with } \\
\text { interviews and } \\
\text { participant } \\
\text { observation) } \\
\text { N:43 } \\
\text { Number of }\end{array}$ & $\begin{array}{l}\text { Quantitative: } \\
\text { information on } \\
\text { the questions } \\
\text { not provided. } \\
\text { Qualitative: } \\
\text { interview guide } \\
\text { provided. Core } \\
\text { questions related } \\
\text { to the review: } \\
\text { Does living in } \\
\text { this community } \\
\text { affect how you } \\
\text { think and feel } \\
\text { about the aging } \\
\text { process and any } \\
\text { challenges that }\end{array}$ & $\begin{array}{l}\text { PSYCHOSOCIAL } \\
\text { DETERMINANTS } \\
\text { OF HEALTH } \\
\text { Social support: } \\
\text { Residents were } \\
\text { willing to help } \\
\text { others, ask for } \\
\text { help when } \\
\text { needed and } \\
\text { accept help. } \\
\text { Sense of } \\
\text { community: } \\
\text { Development } \\
\text { and satisfaction } \\
\text { of a sense of } \\
\text { community and }\end{array}$ \\
\hline
\end{tabular}


Table 2 Description of the main health-related results found in the cohousing projects (Continued)

\begin{tabular}{ll}
\hline 1st Author, & Aim \\
year & \\
\hline & \\
& \\
Glass, 2016 & \\
& \\
& \\
To determine if \\
neighbourhoods, \\
each based on \\
the cohousing \\
model promote \\
development of \\
social resources \\
for their \\
residents.
\end{tabular}

Characteristics of the projects

$\begin{aligned} & \text { Methodology } \\ & \text { (design or } \\ & \text { technique) }\end{aligned}$
projects
studied: 1

Cohousing country: USA Age target: Elderly Co-ownership: No

studied:

can come with

that process? If

so, how?

How is the

mutual support

working out?

Have your

expectations

changed?

Main results

mutually

supportive

processes.

Bring prospective

residents

together

regularly while

the buildings are

under

construction to

begin to build a sense of

community and

to discuss

expectations

about the

community.

Social networks measured by

Lubben Social

Network Scale.

Neighbouring

support through

four items.

Satisfaction with

the

neighbourhood

community

measured by

seven items.

PSYCHOSOCIAL

DETERMINANTS

OF HEALTH

Social support:

The mutual

support most

frequently

reported was

sharing of

knowledge to

help someone

(informational),

lending/

borrowing things

(functional), and

listening/

supporting when someone had a

personal problem (emotional).

Social isolation:

Living in an

intentional

neighbourhood

reduces social

isolation by

increasing social

resources.

Sense of

community:

Participants were

very dissatisfied

with sense of

community or

feelings part of

community.

Sense of

security: $77,6 \%$

were very

satisfied with

security and

safety from

crime.

To assess life in co-housing and the beneficial results of living together in relation

Cohousing country: USA

Age target:

Elderly

Co-ownership:
Mixed methods Quantitative: Quantitative

(cross-sectional without group) in 2012 information on

the questions

not provided.

Qualitative:
PSYCHOSOCIAL

DETERMINANTS

OF HEALTH

Social support:

An increase of 
Table 2 Description of the main health-related results found in the cohousing projects (Continued)

\begin{tabular}{|c|c|c|c|c|c|}
\hline $\begin{array}{l}1 \text { st Author, } \\
\text { year }\end{array}$ & Aim & $\begin{array}{l}\text { Characteristics } \\
\text { of the projects }\end{array}$ & $\begin{array}{l}\text { Methodology } \\
\text { (design or } \\
\text { technique) }\end{array}$ & Instruments & Main results \\
\hline & to ageing. & No & $\begin{array}{l}\text { Qualitative } \\
\text { (cross-sectional; } \\
\text { in-depth inter- } \\
\text { views) in } 2009 \\
\mathbf{N}: 31 \\
\text { Number of } \\
\text { projects } \\
\text { studied: } 1\end{array}$ & $\begin{array}{l}\text { interview guide } \\
\text { provided. Core } \\
\text { questions related } \\
\text { to the review: } \\
\text { Why did you } \\
\text { choose to move } \\
\text { here? Why did } \\
\text { you choose an } \\
\text { elder-only com- } \\
\text { munity? How is } \\
\text { the mutual sup- } \\
\text { port working } \\
\text { out? Have your } \\
\text { expectations } \\
\text { changed? }\end{array}$ & $\begin{array}{l}\text { mutual support, } \\
\text { sense of safety } \\
\text { and acceptance } \\
\text { of aging was } \\
\text { perceived. } \\
\text { Residents } \\
\text { explained that } \\
\text { they were } \\
\text { prepared to help } \\
\text { each other and } \\
\text { learning to age } \\
\text { well together. } \\
\text { The } 89 \% \text { say } \\
\text { there is more } \\
\text { mutual support } \\
\text { in cohousing. } \\
\text { Social isolation } \\
\text { Over } 90 \% \text { of } \\
\text { residents } \\
\text { reported } \\
\text { agreement or } \\
\text { satisfaction on } \\
\text { feeling safe, less } \\
\text { worry and } \\
\text { lessening of } \\
\text { social isolation. } \\
\text { Sense of } \\
\text { security } \\
\text { Residents } \\
\text { showed feelings } \\
\text { of security } \\
\text { related to mutual } \\
\text { support, } \\
\text { socialising and } \\
\text { companionship } \\
\text { among residents. } \\
\text { All residents } \\
\text { indicated that } \\
\text { living in } \\
\text { cohousing makes } \\
\text { feeling safe. }\end{array}$ \\
\hline $\begin{array}{l}\text { Jolanki and } \\
\text { Vilkko, } 2015\end{array}$ & $\begin{array}{l}\text { To study what a } \\
\text { "sense of } \\
\text { community" } \\
\text { meant to the } \\
\text { residents and } \\
\text { how a sense of } \\
\text { community } \\
\text { becomes visible } \\
\text { in daily life. }\end{array}$ & $\begin{array}{l}\text { Cohousing } \\
\text { country: Finland } \\
\text { Age target: } \\
\text { Elderly } \\
\text { Co-ownership: } \\
\text { No }\end{array}$ & $\begin{array}{l}\text { Mixed methods } \\
\text { Quantitative } \\
\text { (cross-sectional } \\
\text { without } \\
\text { comparison } \\
\text { group) } \\
\text { Qualitative } \\
\text { (cross-sectional; } \\
\text { semi-structured } \\
\text { interviews and } \\
\text { groups } \\
\text { discussions) } \\
\mathrm{N}: 6 \text { discussants } \\
\text { and } 41 \text { surveyed } \\
\text { Number of } \\
\text { projects } \\
\text { studied: } 1\end{array}$ & $\begin{array}{l}\text { Quantitative: } \\
\text { information on } \\
\text { the questions } \\
\text { not provided. } \\
\text { Qualitative: } \\
\text { Core questions } \\
\text { related to the } \\
\text { review: What } \\
\text { kind of meanings } \\
\text { are given to a } \\
\text { "sense of } \\
\text { community" by } \\
\text { the residents of } \\
\text { the co- housing } \\
\text { community? } \\
\text { How does a } \\
\text { "sense of } \\
\text { community" } \\
\text { become visible } \\
\text { in the daily life of } \\
\text { the community, } \\
\text { according to the } \\
\text { residents? }\end{array}$ & $\begin{array}{l}\text { PSYCHOSOCIAL } \\
\text { DETERMINANTS } \\
\text { OF HEALTH } \\
\text { Social support: } \\
\text { Community as a } \\
\text { source of social } \\
\text { and practical } \\
\text { support for } \\
\text { residents. } \\
\text { Sense of } \\
\text { community: } \\
\text { Sense of } \\
\text { community } \\
\text { understood as a } \\
\text { sense of } \\
\text { togetherness, } \\
\text { belonging and } \\
\text { trust, created } \\
\text { through } \\
\text { community } \\
\text { activities, doing } \\
\text { things together, } \\
\text { and have mutual } \\
\text { support. } \\
\text { Sense of }\end{array}$ \\
\hline
\end{tabular}


Table 2 Description of the main health-related results found in the cohousing projects (Continued)

$\begin{aligned} & \text { 1st Author, Aim } \\ & \text { year }\end{aligned}$
of the projects

Methodology Instruments
(design or technique)

$\begin{array}{ll}\text { Kehl and Then, } & \text { To assess the } \\ & \text { effects of multi- } \\ & \text { generation } \\ \text { cohousing } & \text { developments on } \\ & \text { the residents, } \\ & \text { health conditions } \\ & \text { and social } \\ & \text { support. }\end{array}$

Labit, 2015

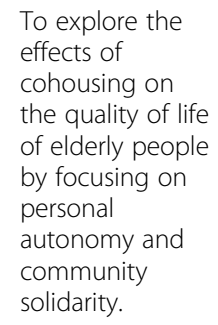

Cohousing
country:
Germany
Age target:
Intergenerational
Co-ownership:
No

Quantitative

(Cross-sectional

with comparison group)

N: 313 program

group; 428

control group

Number of

projects

studied: 4

Cohousing
country: 2
Germany, 1
Sweden, 2 UK.
Age target:
Intergenerational
Co-ownership:
No

Cohousing

Germany,

Age target:

Co-ownership:

Qualitative

(cross-sectional;

semi-structured

interviews, par-

ticipants obser-

vation and

photographic

record)

N: 30 with

residents aged

over 50

Number of

projects

studied: 5
Main results

security: Trust in

the community

as a collective

unit that

supported its

residents, trust in

other residents,

and always

having someone

to turn to create

a sense of

security and

safety.

\section{General health} was measured by

self-perceived health

Care level was measured with scale from 0 points to 3 points.

Social support measured with scale from 0 points to 5 points.

Interview guide not provided.

SELF-PERCEIVED

PHYSICAL AND

MENTAL HEAL

TH

No significant

differences in

subjective health

assessment.

$13 \%$ of the

programme

group

respondents are in need of care

compared to

$22 \%$ in the

control group.

PSYCHOSOCIAL

DETERMINANTS

OF HEALTH

Social support:

Cohousing

participants show

more social

support and

social cohesion

than the control

group.

\section{QUALITY OF}

LIFE AND WELL-

BEING

Cohousing is

considered a

good housing

option for older

people as it

improves the

quality of their

lives by focusing

on personal

autonomy and

community

solidarity.

PSYCHOSOCIAL

DETERMINANTS

OF HEALTH

Social support:

Mutual assistance

is often

described as the

result of affinity,

although mutual

assistance and 
Table 2 Description of the main health-related results found in the cohousing projects (Continued)

$\begin{array}{ll}\begin{array}{l}1 \text { st Author, Aim } \\ \text { year }\end{array} & \begin{array}{l}\text { Characteristics } \\ \text { of the projects }\end{array}\end{array}$

Methodology Instruments
(design or technique)

\begin{tabular}{|c|c|c|c|c|c|}
\hline $\begin{array}{l}\text { Labit and } \\
\text { Dubost, } 2016\end{array}$ & $\begin{array}{l}\text { To learn about } \\
\text { the experiences } \\
\text { of residents living } \\
\text { in a model of } \\
\text { cohousing based } \\
\text { on solidarity } \\
\text { between elderly } \\
\text { people and } \\
\text { families in } \\
\text { Germany. }\end{array}$ & $\begin{array}{l}\text { Cohousing } \\
\text { country: } \\
\text { Germany } \\
\text { Age target: } \\
\text { Intergenerational } \\
\text { Co-ownership: } \\
\text { No }\end{array}$ & $\begin{array}{l}\text { Qualitative } \\
\text { (cross-sectional; } \\
\text { semi-structured } \\
\text { interviews) } \\
\mathrm{N}: 10 \text { Cologne; } \\
8 \text { Berlin } \\
\text { Number of } \\
\text { projects } \\
\text { studied: } 2\end{array}$ & $\begin{array}{l}\text { Interview guide } \\
\text { not provided. }\end{array}$ & $\begin{array}{l}\text { PSYCHOSOCIAL } \\
\text { DETERMINANTS } \\
\text { OF HEALTH } \\
\text { Social support: } \\
\text { Creation of a } \\
\text { strong } \\
\text { attachment in } \\
\text { mothers (single } \\
\text { or not) because } \\
\text { the community } \\
\text { makes daily life } \\
\text { easier } \\
\text { Intergenerational } \\
\text { solidarity was not } \\
\text { evident although } \\
\text { seniors reported } \\
\text { receiving help } \\
\text { when they } \\
\text { requested. } \\
\text { Older participants } \\
\text { are discouraged } \\
\text { by conflicts } \\
\text { (budget } \\
\text { management } \\
\text { and maintenance } \\
\text { of common } \\
\text { areas) }\end{array}$ \\
\hline $\begin{array}{l}\text { Markle et al., } \\
2015\end{array}$ & $\begin{array}{l}\text { To explore } \\
\text { cohousing } \\
\text { residents' } \\
\text { experience of } \\
\text { social support in } \\
\text { the USA. }\end{array}$ & $\begin{array}{l}\text { Cohousing } \\
\text { country: USA } \\
\text { Age target: } \\
\text { Intergenerational } \\
\text { Co-ownership: } \\
\text { Yes }\end{array}$ & $\begin{array}{l}\text { Mixed method } \\
\text { Quantitative } \\
\text { (cross-sectional } \\
\text { with comparison } \\
\text { group) } \\
\text { Qualitative } \\
\text { (cross-sectional; } \\
\text { semi-structured } \\
\text { interview) } \\
\mathrm{N}: 60 \text { living in } \\
\text { cohousing; } 65 \\
\text { not living in } \\
\text { cohousing } \\
\mathrm{N}: 10 \text { interviews } \\
\text { Number of } \\
\text { projects } \\
\text { studied: } \\
\text { Unknown }\end{array}$ & $\begin{array}{l}\text { Quantitative: } \\
\text { Social support } \\
\text { was measured } \\
\text { with three scales: } \\
\text { Social Provisions } \\
\text { Scale (SPS), Social } \\
\text { support given } \\
\text { (SSG) and Social } \\
\text { support received } \\
\text { (SSR). } \\
\text { Qualitative: } \\
\text { interview guide } \\
\text { provided. Core } \\
\text { questions related } \\
\text { to the review: } \\
\text { How do you give } \\
\text { and/or receive } \\
\text { support from } \\
\text { other people in } \\
\text { your cohousing } \\
\text { community? } \\
\text { How has living in } \\
\text { cohousing }\end{array}$ & $\begin{array}{l}\text { PSYCHOSOCIAL } \\
\text { DETERMINANTS } \\
\text { OF HEALTH } \\
\text { Social support: } \\
\text { People who live } \\
\text { in cohousing } \\
\text { receive and give } \\
\text { more social } \\
\text { support than } \\
\text { people who do } \\
\text { not. Moreover, } \\
\text { cohousing } \\
\text { participants } \\
\text { indicated that } \\
\text { they felt more } \\
\text { supported in } \\
\text { cohousing } \\
\text { compared to } \\
\text { previous living } \\
\text { situations. } \\
\text { Sense of } \\
\text { community: } \\
\text { Elderly are aware }\end{array}$ \\
\hline
\end{tabular}

solidarity

between

generations was

also reported.

Sense of

security:

Solidarity and

good

neighbourly

relations foster a

sense of security,

something that

was most

evident in senior

participants.

PSYCHOSOCIAL

OF HEALTH

Social support:

Creation of a

mothers (single

or not) because

the community

s daily life

Intergenerational

solidarity was not

dent although

receiving help

when they

Older participants

are discouraged

conflicts

management

and maintenance

of common

areas)

cohousing

residents'

oxperience of

cial support in

country: USA

PYCHOSOCIAL

DETERMINANTS

OF HEALTH

group)

Qualitative

in cohousing

receive and give

cohousing: 65

not living in

cohousing

Number of

projects

studied:

cohousing

Elderly are aware 
Table 2 Description of the main health-related results found in the cohousing projects (Continued)

\begin{tabular}{|c|c|c|c|c|c|}
\hline $\begin{array}{l}\text { 1st Author, } \\
\text { year }\end{array}$ & Aim & $\begin{array}{l}\text { Characteristics } \\
\text { of the projects }\end{array}$ & $\begin{array}{l}\text { Methodology } \\
\text { (design or } \\
\text { technique) }\end{array}$ & Instruments & Main results \\
\hline & & & & $\begin{array}{l}\text { impacted or } \\
\text { changed your } \\
\text { life? }\end{array}$ & $\begin{array}{l}\text { that they can } \\
\text { receive help from } \\
\text { the community } \\
\text { in their ageing } \\
\text { and with their } \\
\text { health problems. } \\
\text { The sense of } \\
\text { community was } \\
\text { a reason for } \\
\text { joining } \\
\text { cohousing. }\end{array}$ \\
\hline $\begin{array}{l}\text { Motevasel, } \\
2006\end{array}$ & $\begin{array}{l}\text { To know the } \\
\text { expectations and } \\
\text { differences } \\
\text { between } \\
\text { residents in } \\
\text { rental apartments } \\
\text { and tenant- } \\
\text { owned housing } \\
\text { cooperative. }\end{array}$ & $\begin{array}{l}\text { Cohousing } \\
\text { country: Sweden } \\
\text { Age target: } \\
\text { Elderly } \\
\text { Co-ownership: } \\
\text { Yes }(2 / 4)\end{array}$ & $\begin{array}{l}\text { Qualitative } \\
\text { (cross-sectional; } \\
\text { in-depth inter- } \\
\text { views with com- } \\
\text { parison group) } \\
\mathbf{N}: 16 \text { seniors in } \\
\text { rental } \\
\text { apartments; } 12 \\
\text { seniors in } \\
\text { cooperatives } \\
\text { Number of } \\
\text { projects } \\
\text { studied: } 4\end{array}$ & $\begin{array}{l}\text { Interview guide } \\
\text { provided. Core } \\
\text { questions related } \\
\text { to the review: } \\
\text { Why have the } \\
\text { residents chosen } \\
\text { senior housing? } \\
\text { What are the } \\
\text { differences } \\
\text { between } \\
\text { residents in } \\
\text { rental } \\
\text { apartments and } \\
\text { tenant-owned } \\
\text { housing } \\
\text { cooperatives? } \\
\text { What advantages } \\
\text { and } \\
\text { disadvantages do } \\
\text { the residents } \\
\text { think that senior } \\
\text { housing has? }\end{array}$ & $\begin{array}{l}\text { PSYCHOSOCIAL } \\
\text { DETERMINANTS } \\
\text { OF HEALTH } \\
\text { Social support: } \\
\text { Socialisation, } \\
\text { activities and } \\
\text { community were } \\
\text { perceived } \\
\text { positive both, in } \\
\text { the rental } \\
\text { apartments and } \\
\text { the cohousing } \\
\text { cooperatives. } \\
\text { Social isolation: } \\
\text { The architectural } \\
\text { design forced } \\
\text { socialisation and } \\
\text { it was not always } \\
\text { a positive } \\
\text { experience. } \\
\text { Nevertheless, it } \\
\text { avoided the } \\
\text { social isolation of } \\
\text { the elderly who } \\
\text { were sick and } \\
\text { frail. } \\
\text { Sense of } \\
\text { community: The } \\
\text { informants did } \\
\text { not think that } \\
\text { they have } \\
\text { chosen their } \\
\text { present housing } \\
\text { out of a desire } \\
\text { for security or } \\
\text { social } \\
\text { community. } \\
\text { However, they } \\
\text { have come to } \\
\text { appreciate that } \\
\text { there is a } \\
\text { community in } \\
\text { the senior } \\
\text { housing. }\end{array}$ \\
\hline $\begin{array}{l}\text { Nusbaum, } \\
2010\end{array}$ & $\begin{array}{l}\text { To understand } \\
\text { how creating and } \\
\text { living in an elder } \\
\text { co-housing com- } \\
\text { munity has im- } \\
\text { pacted residents' } \\
\text { sense of auton- } \\
\text { omy, a critical } \\
\text { component of } \\
\text { psychological }\end{array}$ & $\begin{array}{l}\text { Cohousing } \\
\text { country: USA } \\
\text { Age target: } \\
\text { Elderly } \\
\text { Co-ownership: } \\
\text { No }\end{array}$ & $\begin{array}{l}\text { Qualitative } \\
\text { (cross-sectional; } \\
\text { in-depth } \\
\text { interviews) } \\
\text { N:10 } \\
\text { Number of } \\
\text { projects } \\
\text { studied: } 1\end{array}$ & $\begin{array}{l}\text { Interview guide } \\
\text { provided. Core } \\
\text { questions related } \\
\text { to the review: } \\
\text { Can you tell me } \\
\text { about a typical } \\
\text { day here at } \\
\text { Capitol Court? } \\
\text { How is living at } \\
\text { Capitol Court }\end{array}$ & $\begin{array}{l}\text { QUALITY OF } \\
\text { LIFE AND WELL- } \\
\text { BEING } \\
\text { The participants } \\
\text { deeply valued } \\
\text { both their own } \\
\text { autonomy and } \\
\text { their fellow } \\
\text { residents. } \\
\text { Participants }\end{array}$ \\
\hline
\end{tabular}


Table 2 Description of the main health-related results found in the cohousing projects (Continued)

\begin{tabular}{|c|c|c|c|c|c|}
\hline $\begin{array}{l}\text { 1st Author, } \\
\text { year }\end{array}$ & Aim & $\begin{array}{l}\text { Characteristics } \\
\text { of the projects }\end{array}$ & $\begin{array}{l}\text { Methodology } \\
\text { (design or } \\
\text { technique) }\end{array}$ & Instruments & Main results \\
\hline & $\begin{array}{l}\text { well-being in old } \\
\text { age. }\end{array}$ & & & $\begin{array}{l}\text { going for you? } \\
\text { How important is } \\
\text { autonomy to } \\
\text { you, or the } \\
\text { meaning of } \\
\text { deciding what } \\
\text { you want in your } \\
\text { life? Have you } \\
\text { always been that } \\
\text { way, or is that a } \\
\text { quality that has } \\
\text { become more } \\
\text { important as you } \\
\text { have gotten } \\
\text { older? }\end{array}$ & $\begin{array}{l}\text { reported their } \\
\text { autonomy was } \\
\text { not } \\
\text { compromised by } \\
\text { functioning as a } \\
\text { cohesive group, } \\
\text { indeed various } \\
\text { aspects of group } \\
\text { life foster } \\
\text { individual } \\
\text { autonomy. } \\
\text { Living in an } \\
\text { environment } \\
\text { with a high } \\
\text { degree of } \\
\text { autonomy } \\
\text { favours } \\
\text { opportunities to } \\
\text { participate and } \\
\text { contribute, } \\
\text { resulting in an } \\
\text { improvement in } \\
\text { different } \\
\text { competences } \\
\text { and skills. } \\
\text { PSYCHOSOCIAL } \\
\text { DETERMINANTS } \\
\text { OF HEALTH } \\
\text { Social support: } \\
\text { Participants cared } \\
\text { greatly about the } \\
\text { quality of their } \\
\text { relationships with } \\
\text { each other, and } \\
\text { yet they also } \\
\text { cared about } \\
\text { quantity of time } \\
\text { spent together. }\end{array}$ \\
\hline
\end{tabular}

Pedersen, 2015 To describe how Cohousing the residents have adapted to the individual and collective challenges in a Danish senior cohousing

\section{country:}

Denmark

Age target:

Elderly

Co-ownership: No
Mixed method

Quantitative

(cross-sectional without group comparison)

Qualitative (cross-sectional; in-depth interviews) N: 643 surveyed and unknown interviews)

Number of projects studied: Unknown
Quantitative: The questionnaire collected topics about the social interaction in the facilities and residents' perceptions of the advantages and challenges of living in a senior $\mathrm{CO}^{-}$ housing community. Measures not provided. Qualitative:

Core questions related to the review: Why did the residents choose to spend their old age in a co-housing community? Was it difficult to recruit new members for the
PSYCHOSOCIAL DETERMINANTS OF HEALTH Social support: Social networks and satisfaction with housing increased compared to the previous housing situation. Interviews indicated that social and practical activities played an important role in residents' lives and promoted closer friendships. Sense of security: Most residents valued the sense of security they gained from living in an environment 
Table 2 Description of the main health-related results found in the cohousing projects (Continued)

\begin{tabular}{ll}
\hline $\begin{array}{l}\text { 1st Author, } \\
\text { year }\end{array}$ & Aim \\
\hline & \\
Philippsen, & $\begin{array}{l}\text { To know the } \\
\text { degree of social } \\
\text { integration of the } \\
\text { residents into } \\
\text { their residential } \\
\text { group and the } \\
\text { mechanisms by } \\
\text { which the } \\
\text { integration takes } \\
\text { place. }\end{array}$
\end{tabular}

Characteristics
of the projects f projects

$\begin{aligned} & \text { Methodology } \\ & \text { (design or } \\ & \text { technique) }\end{aligned}$

Quantitative
(cross-sectional
without
comparison
group)
N: 220 adults
Number of
projects
studied: 7

$\begin{array}{ll}\begin{array}{l}\text { Cohousing } \\ \text { country: }\end{array} & \begin{array}{l}\text { Quantitative } \\ \text { (cross-sectional }\end{array} \\ \text { Germany } & \text { without } \\ \text { Age target: } 6 & \text { comparison } \\ \text { Intergenerational } & \text { group) } \\ \text { and 1 Senior } & \mathrm{N}: 220 \text { adults } \\ \text { Co-ownership: } & \text { Number of } \\ \text { Yes (1/7 projects) } & \begin{array}{l}\text { projects } \\ \text { studied: } 7\end{array}\end{array}$

$\begin{array}{lll}\text { Rodríguez- } & \text { To explore } & \text { Cohousing } \\ \text { Alonso and } & \text { personal } & \text { country: Spain } \\ \text { Argemir, 2017 } & \text { autonomy, } & \text { Age target: } \\ & \text { organisation of } & \text { Elderly } \\ & \text { physical space } & \text { Co-ownership: } \\ & \text { and collective } & \text { No } \\ & \text { self-management } & \\ & \text { in the senior co- } & \\ & \text { housing } & \\ & \text { cooperative. }\end{array}$

$\begin{array}{ll}\text { board of } & \text { where people } \\ \text { residents? } & \text { knew each other } \\ & \text { well. }\end{array}$

The

questionnaire comprises three thematic blocks with 71

questions: 1) questions about life in the housing project, 2) questions about life situation and personal relationships and 3) general questions about the person. Social support was assessed by the study of social networks and 10 questions based on the Fischer instrument and adapted to the special conditions in housing projects, covering instrumental and emotional support.

Qualitative
(cross-sectional;
in-depth inter-
views, partici-
pant observation
and a group dis-
cussion
workshop)
$\mathrm{N}: 29$
Number of
projects
studied: 1

Interview guide not provided. Group discussion workshop focus on reasons for dismissing family and senior residence as primary options for care and how care is materialised in the cohousing.
Main results

PSYCHOSOCIAL DETERMINANTS Social support: 83-95\% of residents have obtained instrumental or emotional support and 75$88 \%$ have given support.

93\% of the inhabitants believe that it is possible to make close friendships in cohousing. Although, elderly residents have more friendships than younger ones.

Residents who regularly attend cohousing social gatherings are much more likely to be friends than residents who attend meetings only occasionally or never, the closer residents felt, the more likely they were to support each other, both emotionally and instrumentally. Residents of all seven projects indicated more instrumental social support (help with cures, housework, etc. than emotional support.

\section{QUALITY OF} LIFE AND WELLBEING

The ability to decide and manage the forms and timing of self-care promotes physical, emotional, and social well-being. PSYCHOSOCIAL DETERMINANTS OF HEALTH 
Table 2 Description of the main health-related results found in the cohousing projects (Continued)

\begin{tabular}{ll}
\hline $\begin{array}{l}\text { 1st Author, Aim } \\
\text { year }\end{array}$ & $\begin{array}{l}\text { Characteristics } \\
\text { of the projects }\end{array}$ \\
\hline
\end{tabular}

Methodology Instruments
(design or technique)

\begin{tabular}{|c|c|c|c|c|c|}
\hline Ruiu, 2015 & $\begin{array}{l}\text { To assess } \\
\text { whether } \\
\text { cohousing } \\
\text { communities (the } \\
\text { case of Threshold } \\
\text { Centre) might } \\
\text { generate positive } \\
\text { effects in terms } \\
\text { of social housing. }\end{array}$ & $\begin{array}{l}\text { Cohousing } \\
\text { country: USA } \\
\text { Age target: } \\
\text { Intergenerational } \\
\text { Co-ownership: } \\
\text { Si }\end{array}$ & $\begin{array}{l}\text { Qualitative } \\
\text { (cross-sectional; } \\
\text { semi-structured } \\
\text { interviews and } \\
\text { cognitive maps) } \\
\mathrm{N}: 18 \\
\text { Number of } \\
\text { projects } \\
\text { studied: } 1\end{array}$ & $\begin{array}{l}\text { Interview guide } \\
\text { not provided } \\
\text { instead a list of } \\
\text { topics was } \\
\text { provide, topics } \\
\text { related to the } \\
\text { review were: } \\
\text { Decision-making } \\
\text { process; Physical } \\
\text { layout and social } \\
\text { life; Social dy- } \\
\text { namics and priv- } \\
\text { acy (public and } \\
\text { private spaces); } \\
\text { Shared values } \\
\text { and "ideologies" } \\
\text { Relations with } \\
\text { the outside; } \\
\text { Safety. }\end{array}$ & $\begin{array}{l}\text { PSYCHOSOCIAL } \\
\text { DETERMINANTS } \\
\text { OF HEALTH } \\
\text { Social support: } \\
\text { There is informal } \\
\text { mutual support } \\
\text { among residents } \\
\text { and in the } \\
\text { neighbourhood } \\
\text { Sense of } \\
\text { community: } \\
\text { Participation in } \\
\text { all stages of the } \\
\text { process, in } \\
\text { addition to self- } \\
\text { management, } \\
\text { contributes to a } \\
\text { sense of } \\
\text { community } \\
\text { Designing and } \\
\text { managing } \\
\text { common spaces } \\
\text { helps to define } \\
\text { community life } \\
\text { and a collective } \\
\text { perception } \\
\text { Sense of } \\
\text { security: High } \\
\text { sense of security } \\
\text { thanks to the } \\
\text { physical layout of } \\
\text { the community. }\end{array}$ \\
\hline $\begin{array}{l}\text { Tchoukaleyska, } \\
2011\end{array}$ & $\begin{array}{l}\text { To know how } \\
\text { cohousing } \\
\text { communities can } \\
\text { reduce the risks } \\
\text { associated with } \\
\text { living in an urban } \\
\text { context and are a } \\
\text { desirable place to } \\
\text { raise children. }\end{array}$ & $\begin{array}{l}\text { Cohousing } \\
\text { country: Canada } \\
\text { Age target: } \\
\text { intergenerational } \\
\text { Co-ownership: } \\
\text { Yes }\end{array}$ & $\begin{array}{l}\text { Qualitative } \\
\text { (cross-sectional; } \\
\text { semi-structured } \\
\text { interviews) } \\
\mathbf{N}: 5 \text { residents } \\
\text { (three family } \\
\text { interviews) } \\
\text { Number of } \\
\text { projects } \\
\text { studied: } 1\end{array}$ & $\begin{array}{l}\text { Interview guide } \\
\text { not provided }\end{array}$ & $\begin{array}{l}\text { PSYCHOSOCIAL } \\
\text { DETERMINANTS } \\
\text { OF HEALTH } \\
\text { Social support: } \\
\text { Cohousing } \\
\text { encourage social } \\
\text { relationship, } \\
\text { social support } \\
\text { among families } \\
\text { and allows } \\
\text { children to meet } \\
\text { friends of } \\
\text { different ages. } \\
\text { Many } \\
\text { participants also } \\
\text { reported the } \\
\text { exchange of } \\
\text { practical, } \\
\text { pragmatic }\end{array}$ \\
\hline
\end{tabular}

OF HEALTH

Social support:

Autonomy is

only possible

through

collective

support and

social relations of

solidarity.

Physical spaces

also allow for

social interaction

that leads to

emotional bonds. 
Table 2 Description of the main health-related results found in the cohousing projects (Continued)

\begin{tabular}{ll}
\hline $\begin{array}{l}\text { 1st Author, Aim } \\
\text { year }\end{array}$ & $\begin{array}{l}\text { Characteristics } \\
\text { of the projects }\end{array}$
\end{tabular}

Methodology Instruments
(design or technique)
Tyvimaa, 2011 To discuss residents' views of social and physical environments in a cohousing and in a senior housing setting in Finland.
Cohousing country: Finland Age target: Elderly No-

O

Mixed methods Quantitative:

Quantitative (cross-sectional with comparison group)

Qualitative (cross-sectional; in-depth interviews) $\mathbf{N}$ : 34 group intervention; 64 group comparison $\mathbf{N}: 14$ interviews Number of projects studied: 2
Main results

support within their community, involving sharing objects, borrowing cars, or offering rides, and caring for each other's homes, plants, and pets while they were away Sense of community: There is a sense of community and is a reason behind the selection of cohousing for their families, parents indicate

Sense of security: There were a common desire to provide a family-oriented environment and emotionally and physically secure for children.

PSYCHOSOCIAL

DETERMINANTS OF HEALTH

Social support: Well-designed

common areas activate residents to socialise and organise activities. They use their common areas more actively than residents in conventional housing.

$29 \%$ of cohousing residents and $14.9 \%$ of senior housing residents said they met with neighbours at least once. Social

networking is an integral

component of happiness within the housing setting.

Social isolation: The residents had experienced loneliness or social isolation 
Table 2 Description of the main health-related results found in the cohousing projects (Continued)

\begin{tabular}{llll}
\hline $\begin{array}{l}\text { 1st Author, Aim } \\
\text { year }\end{array}$ & $\begin{array}{l}\text { Characteristics } \\
\text { of the projects }\end{array}$ & $\begin{array}{l}\text { Methodology } \\
\text { (design or } \\
\text { technique) }\end{array}$ & Instruments
\end{tabular}

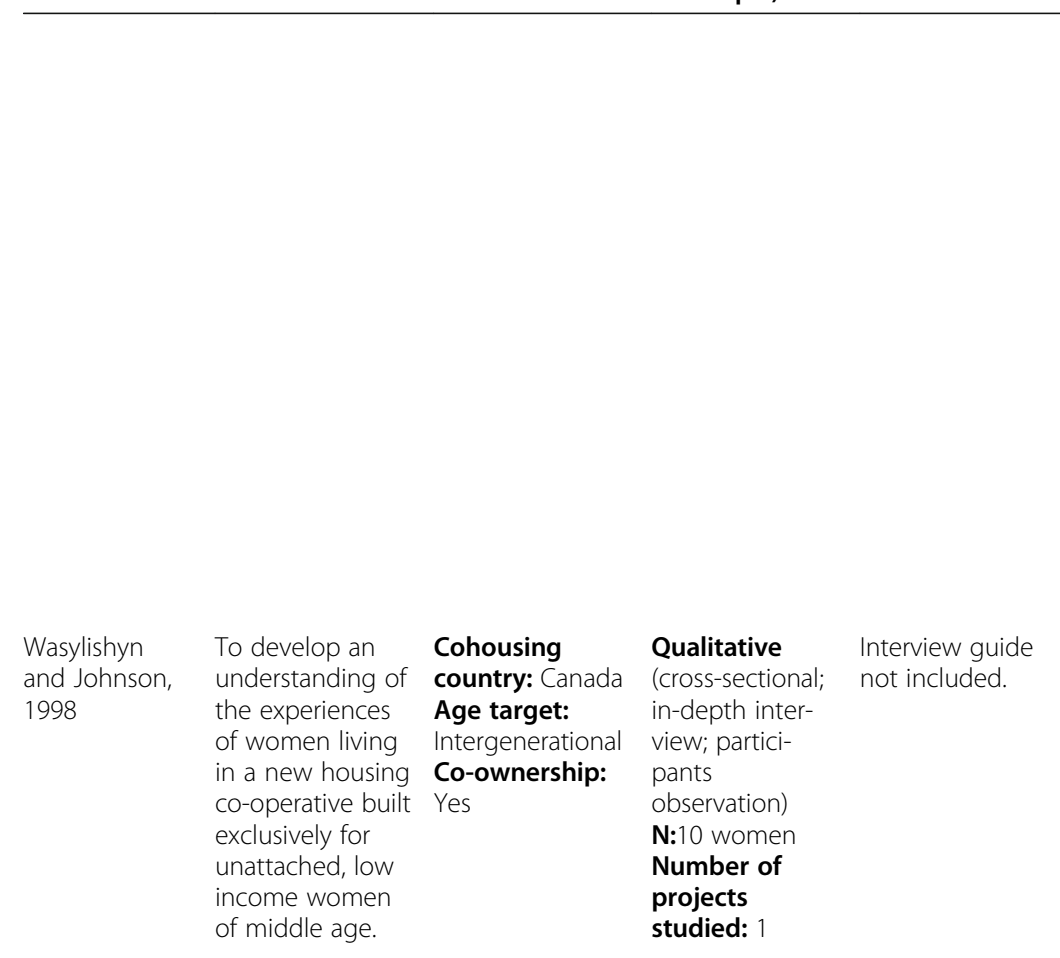

before moving

into co-housing,

after moving that

sense disappears.

Sense of

community:

The sense of

community was

a reason for

choosing to live

in cohousing.

Activities

organised

together connect

the residents

together and

increase the

feeling of sense

of community

SELF-PERCEIVED

PHYSICAL AND

MENTAL HEAL

TH

A deterioration in

physical and/or

mental health

was perceived

after moving into

the co-operative.

PSYCHOSOCIAL

DETERMINANTS

OF HEALTH

Social support:

The increased

sense of control

and social

support inherent

in community life

were not

immediately

apparent.

Sense of

community:

Women

perceived

themselves as a

diverse group

without a

common

identity.

Sense of

security: Less

financial stress

and more sense

of safety.

Williams, 2005 To know how the physical design and management of a cohousing

influences the

social interaction

of the residents.
Cohousing country: USA Age target:

Qualitative (cross-sectional; activity diaries,

Interview guide not provided

PSYCHOSOCIAL DETERMINANTS OF HEALTH

Social support:

The number and diversity of social activities

organised in a community seem to affect levels of 
Table 2 Description of the main health-related results found in the cohousing projects (Continued)

\begin{tabular}{|c|c|c|c|c|c|}
\hline $\begin{array}{l}\text { 1st Author, } \\
\text { year }\end{array}$ & Aim & $\begin{array}{l}\text { Characteristics } \\
\text { of the projects }\end{array}$ & $\begin{array}{l}\text { Methodology } \\
\text { (design or } \\
\text { technique) }\end{array}$ & Instruments & Main results \\
\hline & & & studied: 2 & & $\begin{array}{l}\text { social interaction. } \\
\text { The } \\
\text { management of } \\
\text { indoor } \\
\text { communal } \\
\text { facilities was also } \\
\text { shown to } \\
\text { influence usage } \\
\text { and social } \\
\text { interaction. } \\
\text { Meetings could } \\
\text { potentially } \\
\text { provide the } \\
\text { opportunity for } \\
\text { more social } \\
\text { interaction } \\
\text { amongst } \\
\text { residents. } \\
\text { Density } \\
\text { (proximity) and } \\
\text { layout, the } \\
\text { division of public } \\
\text { and private space } \\
\text { and the quality, } \\
\text { type and } \\
\text { functionality of } \\
\text { communal } \\
\text { spaces appear to } \\
\text { be the key } \\
\text { design factors } \\
\text { influencing social } \\
\text { interaction in } \\
\text { cohousing } \\
\text { developments }\end{array}$ \\
\hline
\end{tabular}

methods [15, 16, 38-41, 51-53] and four quantitative methods [13, 37, 43, 54]. Two studies with a comparison group $[14,37]$ and three studies that compared the actual situation with previous situation [43, 46, 48] reported that social support was more evident in the cohousing model. In addition, the residents' social networks were strengthened after they moved into cohousing [45].

Most studies reported that the cohousing model had beneficial effects on the residents' social support. This effect could be found both in senior [12, 13, 35, 39, 41, 45, $47-50,52,54]$ and intergenerational projects $[14-16,37,40,43,46,53,54]$. One study found beneficial effects of social support among same-generation residents while intergenerational social support was less evident [51].

Three studies indicated less obvious effects. One studied a project targeting low-income women in which social support was not an immediate effect due to the diversity of the residents, although over time it seemed to be able to increase [38]. Other found no significant differences in the increase in social support comparing the perception of cohousing residents with the perception of residents in rental apartments with social activities. However, socialisation patterns were more open and autonomous among cohousing residents [52]. The third states that intergenerational solidarity was not evident [51].

Among studies reporting a beneficial effect on social support, three types of social support can be described: (a) instrumental (or functional) social support involving activities such as borrowing, housework, meal preparation, care during illness or childcare 
Table 3 Number of studies showing a beneficial, neutral or detrimental effect of cohousing on the health outcomes analysed

\begin{tabular}{|c|c|c|c|}
\hline & Beneficial & Neutral & Detrimental \\
\hline $\begin{array}{l}\text { Self-perceived } \\
\text { physical and } \\
\text { mental health }^{\mathrm{a}}\end{array}$ & $\begin{array}{l}3 \text { (Glass, 2012, 2009; Kehl and Then, } \\
\text { 2013) }\end{array}$ & 1 (Kehl and Then, 2013) & $\begin{array}{l}1 \text { (Wasylishyn and } \\
\text { Johnson, 1998) }\end{array}$ \\
\hline $\begin{array}{l}\text { Quality of life } \\
\text { and well-being }\end{array}$ & $\begin{array}{l}5 \text { (Choi and Paulsson, 2011; Cooper and } \\
\text { Rodman, 1994; Labit, 2015; Nusbaum, } \\
\text { 2010; Rodríguez-Alonso and Argemir, } \\
\text { 2017) }\end{array}$ & 1 (Altus and Mathews, 2002) & \\
\hline \multicolumn{4}{|c|}{ Psychosocial determinants of health } \\
\hline $\begin{array}{l}\text { Social } \\
\text { support }^{b}\end{array}$ & $\begin{array}{l}20 \text { (Bamford, 2005; Choi and Paulsson, } \\
\text { 2011; Fromm, 2000; Glass, 2016, 2013, } \\
\text { 2009; Glass and Vander Plaats, 2013; } \\
\text { Jolanki and Vilkko, 2015; Kehl and Then, } \\
\text { 2013; Labit, 2015; Labit and Dubost, 2016; } \\
\text { Markle et al., 2015; Nusbaum, 2010; } \\
\text { Pedersen, 2015; Philippsen, 2014; } \\
\text { Rodríguez-Alonso and Argemir, 2017; } \\
\text { Ruiu, 2015; Tchoukaleyska, 2011; Tyvimaa, } \\
\text { 2011; Williams, 2005) }\end{array}$ & $\begin{array}{l}3 \text { (Labit and Dubost, 2016; } \\
\text { Motevasel, 2006; Wasylishyn } \\
\text { and Johnson, 1998) }\end{array}$ & \\
\hline $\begin{array}{l}\text { Social } \\
\text { isolation }\end{array}$ & $\begin{array}{l}5 \text { (Glass, 2016; Glass and Vander Plaats, } \\
\text { 2013; Motevasel, 2006; Tyvimaa, 2011; } \\
\text { Wasylishyn and Johnson, 1998) }\end{array}$ & & \\
\hline $\begin{array}{l}\text { Sense of } \\
\text { community }^{c}\end{array}$ & $\begin{array}{l}10 \text { (Fromm, 2000; Glass, 2016, 2013, 2009; } \\
\text { Jolanki and Vilkko, 2015; Markle et al., } \\
\text { 2015; Motevasel, 2006; Ruiu, 2015; } \\
\text { Tchoukaleyska, 2011; Tyvimaa, 2011) }\end{array}$ & & $\begin{array}{l}2 \text { (Markle et al., } \\
\text { 2015; Wasylishyn } \\
\text { and Johnson, } \\
\text { 1998) }\end{array}$ \\
\hline $\begin{array}{l}\text { Sense of } \\
\text { security }\end{array}$ & $\begin{array}{l}9 \text { (Bamford, 2005; Fromm, 2000; Glass, } \\
\text { 2016; Glass and Vander Plaats, 2013; } \\
\text { Jolanki and Vilkko, 2015; Pedersen, 2015; } \\
\text { Ruiu, 2015; Tchoukaleyska, 2011; } \\
\text { Wasylishyn and Johnson, 1998) }\end{array}$ & & \\
\hline
\end{tabular}

${ }^{a}$ Kehl and Then, 2013. Article is included in the beneficial and neutral effects boxes. The article reported less use of health care service but no difference on self-perceived health differences

babit and Dubost, 2016. Article is included in the beneficial and neutral effects boxes. The article reported more social support among inhabitants of the same generation and less evident social support across generations 'Markle et al., 2015. Article is included in the beneficial and detrimental effects boxes. The article reported contradictory effects that cannot be classified as neutral

[12-14, 45, 47, 53]; (b) emotional support such as having close friendships, listening or providing support when someone had a personal problem [13, 35, 47]; and (c) recreational support, provided through different social activities organised by residents themselves $[15,50,54]$.

\section{Social isolation}

The five studies assessing social isolation reported less loneliness among cohousing inhabitants using quantitative [13], mixed [48, 50] and qualitative methods [38, 52]. None incorporated a comparison group in the analysis. The four studies targeting the senior population reported that an active lifestyle in settings prevented social isolation and loneliness, which is a general problem among senior residents. Social interaction was enhanced by the architectural design of both indoor and outdoor common spaces, which was also described as an effective way to reduce social isolation [38, 48], in particular among elderly residents who were sick and frail [50]. However, it was not always experienced beneficially since privacy was valued as something that mattered [52]. 


\section{Sense of community}

Evidence was obtained through one study with quantitative methods [13], 6 using mixed methods $[12,14,35,47,50,55]$, including only one with a comparison group [14], and four qualitative designs [16, 38, 52, 53].

Several studies showed a beneficial influence of the cohousing model on the residents' sense of community, both in senior [12, 13, 35, 47, 50, 52] and intergenerational projects $[16,53]$. In contrast, one study about a project for low-income women showed detrimental effects on residents' perception of sense of community. Moreover, another study reported contradictory effects. Living in cohousing increased the sense of community but could also be a source of struggle and fatigue to maintain it [14].

The studies reporting beneficial effects uncovered some sense of community-building pathways. For example, two studies reported that individuals intentionally chose the cohousing model in search of a sense of community [35, 50, 53]. In addition, they outlined the relevance of the residents' engagement pathway throughout all stages of the cohousing development process as a critical source of community building, such as participation in the start-up stages in co-ownership projects $[12,16]$, self-management of common spaces and facilities [16] and the day-to-day community and mutual support [12, 47, 50, 55].

\section{Sense of security}

Nine studies examined the impact of cohousing on the sense of security $[13,16,38$, $45-49,53]$. All of them reported a positive association. The evidence was obtained from five studies using mixed methods [45-49], 3 qualitative studies [16, 38, 53] and one study using quantitative methods [13].

The sense of security gained was found among both senior [13, 45, 47, 48] and intergenerational projects $[16,38,40,46,53]$. The studies found that cohousing increased residents' sense of security through both the physical and the social environment. In addition, it reduced residents' sense of economic insecurity [38]. The physical aspects emphasised were open and well-lit spaces [16], safe children's play areas [53] and a neighbourhood with a rich and pleasant atmosphere [38]. The social features that led to feelings of security were social relationships and trust [47], community coping [48] and social support among neighbours [13, 47, 48]. An economic sense of security among low-income women residents reduced stress, helplessness and frustration [38].

\section{Discussion}

\section{Main findings}

The purpose of this study was to examine all the known evidence on the relationship between communal living arrangements characterised as cohousing and health and wellbeing. Our review indicates that the cohousing model can be positively associated with health outcomes through psychosocial determinants of health, such as increased social support, sense of community and physical, emotional and economic security, as well as reduced social isolation. This association was more evident in cohousing models targeting the older population. Likewise, we found a limited number of studies assessing the direct health effects of the cohousing model. Some studies suggest that cohousing is positively associated with self-perceived physical and mental health outcomes and quality of life and wellbeing. However, extreme caution should be exercised in drawing any conclusions due 
to the dearth of data identified and the study designs used-mostly cross-sectional, with small samples or no comparison group-that precluded causal-based interpretations.

\section{What health outcomes have been studied in relation to cohousing?}

With respect to the effect of cohousing on health outcomes, only 10 studies analysed the effect of cohousing on self-perceived health [35-38, 49] and quality of life and wellbeing [39-44].

The studies evaluating both health and quality of life showed relatively limited reproducibility and comparability. No other subjective health measures are available such as joy, happiness, sense of self-worth and value to others, or other measures related to stress and mental health. There is also a lack of evidence on other objective health measures such as the ability to perform physical, mental and social tasks or healthy behaviours. Other health measures that could be important to assess are health-related quality of life indices. For example, the EuroQoL-5 index is one of the most widely used instruments underpinning economic evaluations, which would allow quantification of quality of life and analysis of health effects in terms of the associated costs of this model compared with conventional housing arrangements.

\section{How could cohousing affect health, quality of life and wellbeing?}

The cohousing model may be positively associated with health status through psychosocial pathways underlying health and illness. These mechanisms would be coherent with the evidence found in measures such as social support $[12-16,35,37,38,40,41$, $43,45,47-54]$, sense of community [12, 16, 35, 38, 46, 47] and sense of security [13, $16,38,47,48,53]$. This finding is consistent with other studies reporting the relationship between social support and health and wellbeing. For example, lack of a social network and support, social isolation and loneliness are linked to poor cardiovascular and mental health outcomes [56]. In contrast, living in a community characterised by higher levels of communication and mobilisation is positively associated with residents' selfrated health status [57], especially in elderly persons. In addition, it has been shown that high social support and participation in social networks alleviates stress in older people, preventing them from developing functional decline [58] and mental health problems [59]. A sense of community has also been positively related to a range of health outcomes and indicators of wellbeing, including life satisfaction and loneliness [60], happiness [61], and quality of life [62].

There is a lack of studies aiming to identify the differential health and wellbeing effects resulting from cohousing models based on co-ownership. We found only one study that comparatively assessed the effect of tenure on quality of life [44]. That study observed no additional benefits among residents living in a model based on coownership tenure. We found some evidence to suggest that the co-ownership regime helped to increase autonomy and a sense of control among residents, which could enhance quality of life [42]. Further research is required on the potential health and quality of life gains among the different tenure arrangements in the cohousing model.

\section{Issues arising from the review}

Over the last few years, cohousing has reappeared in various high-income countries. This has not gone unnoticed by several social sectors such as urbanists, politicians, 
social movements and non-profit organisations, with all of them showing a willingness to promote it. However, we cannot dismiss the possibility that the promotion of this model may increase social and health inequalities. Several studies discussed here [16, 52] have observed unequal access to cohousing projects. Populations from disadvantaged social classes would appear to have fewer opportunities to access them and thus less chance to benefit from the potential positive social and health effects. Therefore, we should not rule out the so-called paradox of promotion in public health, in which health promotion can have undesirable effects and increase health inequalities. This effect has been previously documented in a review of unintended harm in public health interventions [63]. Therefore, the unintended effects of cohousing on social and health inequalities should be considered by entities interested in promoting this model and in future research.

In this review, we found no evidence linking housing affordability and health among the cohousing experiences studied. However, there is some evidence that cohousing provides residential security as residents value living in a home at an affordable price for a long period of time $[16,38,52]$. Housing affordability is recognised as a material pathway to health, and there is substantial evidence linking housing affordability problems with a range of adverse health effects [3, 4] and health inequalities [64]. Potentially, cohousing has been considered a housing model that could help to decrease the commoditisation of housing, since it conceives housing as a social good that prioritises its use value over its exchange value. It is known that commodification of other key areas of a person's life, such as food [65], care [66] or the health care system [67], among others, can lead to worse health. In general, in an intentional housing community, housing construction costs are often less subject to the capital gains of promoters; there is greater long-term stability of housing prices and mutual economic support that results in stable economic and social security for residents, who are less exposed to the precarious conditions of the neo-liberal housing market [18]. In this regard, there is a literature gap in relationship between cohousing and its potential effect on health at the individual and community level through socioeconomic aspects. Therefore, further research is required on the potential health gains associated with the affordability, stability, or collectivisation of economic uncertainties of cohousing living arrangements.

\section{Limitations and strengths}

There is still no consensus on the definition of cohousing models. Some authors have attempted to define it and standardise its use for international communication avoiding the use of inconsistent and vague concepts [9]. This makes the search for evidence less complex and the comparative analysis more reliable. However, most of the studies selected were published before this effort at conceptualisation. Therefore, there may be a bias in the article selection due to divergence in search terms. However, the scoping review method used in this review is more flexible than a systemic review. This enabled us to have more flexible exclusion and inclusion protocols and to include articles that would have been ruled out using other review methods. Another limitation could be bias due to the use of language restrictions. Although the present review used the English, Spanish, French, German and Italian languages, cohousing has a long history in Denmark, and Danish was not a language covered in this review. However, to overcome this limitation, we contacted experts to find relevant references. The references gained 
did not allow us to identify new documents studying the relationship between cohousing and health, although additional information on the cohousing model was obtained that facilitated the discussion of the results obtained.

Despite these limitations, this review provides an important contribution to public health and social policies because, to the best of our knowledge, it is the first review to gather and systematise the scientific evidence related to this housing model, aiming to assess its health and welfare effects. The review also identifies knowledge gaps and could be used to inform future research. Likewise, gathering the present evidence will facilitate the design of evidence-based policies in the cohousing domain. In addition, a strong effort has been made to search for evidence by not limiting it to articles indexed in biomedical databases. The search was also performed in social science databases, enabling us to find articles that, although they were not focused on health effects, included them among their findings.

\section{Conclusions}

This study examined the available evidence on cohousing from a public health perspective. The rationale is that housing is an important determinant of health and health inequalities, and cohousing is a potentially health-enhancing form of community living that raises many expectations for creating vivid social networks, communities and healthy environments. Various studies have provided a relatively consistent picture of the increased psychosocial health benefits of the community dimension and the emotional and social bond of this model of housing. However, more research is needed to address the knowledge gaps identified in this review. Future studies should measure health with objective and/or subjective health outcomes because most studies conducted to date have been performed in relation to psychosocial determinants of health. Furthermore, there is a need for studies with methodological approaches that provide clearer evidence of the effects of cohousing on health. Housing is a collection of components that together affect individuals' lives. In that sense, other cohousing dimensions related to economic aspects, such as cost and stability, or environmental sustainability, their interactions and their impact on health and wellbeing, need to be explored in the future.

\section{Supplementary information}

Supplementary information accompanies this paper at https://doi.org/10.1186/540985-020-00138-1.

Additional file 1. Supplementary 1: Subject headings, keywords and search syntaxes. Supplementary 2: List of experts and organizations contacted

\section{Acknowledgements}

Not applicable.

\section{Authors' contributions}

Study conception, planning, analysis, interpretation, and writing: JC and AR. Study conception, insights for the analysis, and interpretation and writing: AR, LO, AF, AP, AN, KP and CB. All authors have read and approved the revised version of this paper. The corresponding author attests that all listed authors meet authorship criteria and that no others meeting the criteria have been omitted.

Funding

The study is part of the Project "Impacto en salud y bienestar de la vivienda cooperativa en cesión de uso", which received a research grant from the Carlos III Institute of Health, Ministry of Economy and Competitiveness (Spain), awarded on the 2018 call under the Health Strategy Action 2013-2016, within the National Research Program oriented 
to Societal Challenges, within the Technical, Scientific and Innovation Research National Plan 2013-2016, with reference PI18/01761, co-funded with European Union ERDF funds (European Regional Development Fund)"

\section{Availability of data and materials}

Not applicable.

Ethics approval and consent to participate

Not applicable.

\section{Consent for publication}

Not applicable.

\section{Competing interests}

The authors declare that they have no competing interests.

\section{Author details}

${ }^{1}$ Agència de Salut Pública de Barcelona, PI. Lesseps 1, 08023 Barcelona, Spain. ${ }^{2}$ Institut d'Investigació Biomèdica (IIB Sant Pau), C. Sant Quintí 77, 08041 Barcelona, Spain. ${ }^{3}$ Department of Experimental and Health Sciences, Universitat Pompeu Fabra, Doctor Aiguader 88, 08003 Barcelona, Spain. ${ }^{4}$ CIBER Epidemiología y Salud Pública (CIBERESP), Av. Monforte de Lemos 3-5, Pabellón 11. Planta 0, 28029 Madrid, Spain.

Received: 30 June 2020 Accepted: 25 September 2020

Published online: 06 October 2020

\section{References}

1. Borrell C, Malmusi D, Artazcoz L, Diez E. Rodríguez-Sanz IP y. M, Campos P, et al. Propuesta de políticas e intervenciones para reducir las desigualdades sociales en salud en España. Gac Sanit. 2012;26:182-9.

2. Krieger J, Higgins DL. Housing and health: time again for public health action. Am. J. Public Health. American Public Health Association; 2002. p. 758-768.

3. Bonnefoy X. Inadequate housing and health: an overview. Int J Environ Pollut. 2007:30:411-29.

4. Novoa AM, Bosch J, Díaz F, Malmusi D, Darnell M, Trilla C. Impact of the crisis on the relationship between housing and health. Policies for good practice to reduce inequalities in health related to housing conditions. Gac Sanit. SESPAS; 2014; 28:44-50.

5. Gibson M, Petticrew M, Bambra C, Sowden AJ, Wright KE, Whitehead M. Housing and health inequalities: a synthesis of systematic reviews of interventions aimed at different pathways linking housing and health. Health Place. Pergamon. 2011;17:175-84.

6. Ormandy D, Ezratty V. Health and thermal comfort: from WHO guidance to housing strategies. Energy Policy. Copenhagen. Denmark. 2012;49:116-21.

7. Cramm JM, Nieboer AP. Building social capital may protect against loss of well-being among older people. Soc Cap as a Heal Resour Later Life Relev Context. 2015. p. 145-54.

8. Norstrand JA, Glicksman A. Influence of living arrangements of community dwelling older adults on the association between social capital and health. Soc Cap as a Heal Resour Later Life Relev Context. 2015. p. 89-107.

9. Vestbro. Concepts and terminology. Living together - cohousing ideas and realities around the world. Stockholm; 2010.

10. Vestbro DU. From collective housing to cohousing - a summary of research; 2000.

11. Vestbro DU, Horelli L. Design for gender equality: the history of co-housing ideas and realities. Built Environ. 2012;38: 315-35.

12. Glass AP. Lessons learned from a new elder cohousing community; 2013.

13. Glass AP. Resident-managed elder intentional neighborhoods: do they promote social resources for older adults? J Gerontol Soc Work; 2016.

14. Markle EA, Rodgers R, Sanchez W, Ballou M. Social support in the cohousing model of community: a mixed-methods analysis. Community Dev. 2015;46(5):616-31.

15. Williams J. Designing neighbourhoods for social interaction: The case of cohousing; 2005.

16. Ruiu ML. The effects of cohousing on the social housing system: the case of the Threshold Centre; 2015.

17. Sanguinetti A. Transformational practices in cohousing: enhancing residents' connection to community and nature. $J$ Environ Psychol. 2014;40:86-96.

18. Hagbert $P$, Larsen HG, Thörn H, Wasshede C, Larsen HG, Thörn H, et al. Contemporary co-housing in Europe. First. Hagbert P, Larsen HG, Thörn H, Wasshede C, editors. Contemp. Co-housing Eur. Milton Park, Abingdon, Oxon ; New York, NY : Routledge, 2020.: Routledge; 2019.

19. Bredenoord J. Self-managed cooperative housing by mutual-assistance as introduced in Central America between 2004 and 2016 the attractiveness of the 'FUCVAM' model of Uruguay. J Archit Eng Technol. 2017;06:1-9.

20. Lang R, Carriou C, Czischke D. Collaborative housing research (1990-2017): a systematic review and thematic analysis of the field; 2018.

21. Tummers L. Understanding co-housing from a planning perspective: why and how? Urban Res Pract. Routledge. 2015;8:64-78.

22. Jarvis H. Sharing, togetherness and intentional degrowth. Prog Hum Geogr. SAGE Publications Ltd. 2019;43:256-75.

23. Larsen HG. Three phases of Danish cohousing: tenure and the development of an alternative housing form; 2019.

24. Marcus CC. Site planning, building design and a sense of community: an analysis of six cohousing schemes in Denmark, Sweden, and the Netherlands. J Archit Plann Res. 2000;17:146-63.

25. Sanguinetti A. The design of intentional communities: a recycled perspective on sustainable neighborhoods. Behav Soc Issues. 2012;21:5-25.

26. Bamford G. Bringing us home: cohousing and the environmental possibilities of reuniting people with neighbourhoods. Situating Environ Univ Queensl Situating Environ. 2001;2001:36-43. 
27. Brown JR. Comparative analysis of energy consumption trends in cohousing and alternate housing arrangements. Dep Civ Environ Eng. 2004.

28. Williams J. Predicting an American future for cohousing. Futures. 2008;40:268-86.

29. Chatterton P. Towards an agenda for post-carbon cities: lessons from lilac, the uk's first ecological, affordable cohousing community. Int J Urban Reg Res. 2013;37:1654-74.

30. Renz MA. Paving consensus: enacting, challenging, and revising the consensus process in a cohousing community; 2006 .

31. Jakobsen P, Larsen HG. An alternative for whom? The evolution and socio-economy of Danish cohousing. Urban Res Pract. Routledge. 2019;12:414-30.

32. Droste C. German co-housing: an opportunity for municipalities to foster socially inclusive urban development? Urban Res Pract. Routledge. 2015;8:79-92.

33. Lubik A, Kosatsky T. Public health should promote co-operative housing and cohousing. Can J Public Heal. Canadian Journal of Public Health. 2019;110:121-6.

34. Arksey H, O'Malley L. Scoping studies: towards a methodological framework. Int I Soc Res Methodol Theory Pract. 2005;8:19-32.

35. Glass AP. Aging in a community of mutual support: the emergence of an elder intentional cohousing community in the United States; 2009.

36. Glass AP. Elder co-housing in the United States: three case studies. Built Environ. 2012;38:345-63.

37. Kehl K, Then V. Community and civil society returns of multi-generation cohousing in Germany; 2013.

38. Wasylishyn C, Johnson JL. Living in a housing co-operative for low income women: Issues of identity, environment and control. Soc Sci Med. 1998:47:973-81.

39. Nusbaum LE. How the elder co-housing model of living affects residents' experience of autonomy: a self -determination theory perspective. ProQuest Diss Theses. Ann Arbor: The Wright Institute; 2010;77.

40. Labit A. Self-managed co-housing in the context of an ageing population in Europe. Urban Res Pract. 2015;8:32-45.

41. Rodríguez-Alonso N. Argemir DC. La construcción social del cuidado comunitario en La Muralleta, una cooperativa autogestionada para gente mayor. 2017;22:183-98.

42. Cooper M, Rodman MC. Accessibility and quality of life in housing cooperatives. Environ Behav. 1994;26:49-70.

43. Choi JS, Paulsson JAN. Evaluation of common activity and life in Swedish cohousing units. Int I Hum Ecol. 2011;12:133-46.

44. Altus DE, Mathews RM. Comparing the satisfaction of rural seniors with housing co-ops and congregate apartments: Is home ownership important? 2002.

45. Pedersen M. Senior co-housing communities in Denmark; 2015.

46. Fromm D. American cohousing: the first five years. J Archit Plann Res. 2000;17:94-109.

47. Jolanki O, Vilkko A. The meaning of a "sense of community" in a Finnish senior co-housing community. J Hous Elderly. 2015;29:111-25.

48. Glass AP, Vander Plaats RS. A conceptual model for aging better together intentionally. J Aging Stud. 2013;27:428-42.

49. Bamford G. Living together on one's own': cohousing for older people, a new housing type in Denmark and The Netherlands. Australas J Ageing. 2005;24:44-6.

50. Tyvimaa T. Social and physical environments in senior communities: The Finnish experience; 2011.

51. Labit A, Dubost N. Housing and ageing in France and Germany: the intergenerational solution. Housing, Care Support. 2016;19:45-54.

52. Motevasel IN. Senior housing in Sweden - a question of class differences and collective aging: an interview study in rental apartments and housing cooperatives; 2006.

53. Tchoukaleyska R. Co-housing childhoods: parents' mediation of urban risk through participation in intentional communities; 2011.

54. Philippsen C. Fazit. Soz Netzwerke gemeinschaftlichen Wohnprojekten. 1st ed. Verlag Barbara Budrich; 2014. p. 233-268.

55. Meltzer G. Cohousing: verifying the importance of community in the application of environmentalism. J Archit Plann Res. 2000;17:110-32.

56. Leigh-Hunt N, Bagguley D, Bash K, Turner V, Turnbull S, Valtorta N, et al. An overview of systematic reviews on the public health consequences of social isolation and loneliness. Public Health. Elsevier B.V.; 2017;152:157-71.

57. Jung M, Viswanath K. Does community capacity influence self-rated health? Multilevel contextual effects in Seoul. Korea. Soc Sci Med. 2013;77:60-9.

58. Unger JB, Johnson CA, Marks G. Functional decline in the elderly: evidence for direct and stress- buffering protective effects of social interactions and physical activity. Ann Behav Med. Springer New York LLC. 1997;19:152-60.

59. Kawachi I. Social ties and mental health. J Urban Heal Bull New York Acad Med. Springer. 2001;78:458-67.

60. Prezza M, Amici M, Roberti T, Tedeschi $\mathrm{G}$. Sense of community referred to the whole town: its relations with neighboring, Ioneliness, life satisfaction, and area of residence. J Community Psychol. John Wiley \& Sons, Ltd; 2001;29:29-52.

61. Davidson WB, Cotter PR. The relationship between sense of community and subjective well-being: a first look. J Community Psychol. John Wiley \& Sons. Ltd. 1991;19:246-53.

62. Young AF, Russell A, Powers JR. The sense of belonging to a neighbourhood: can it be measured and is it related to health and well being in older women? Soc Sci Med. Pergamon. 2004;59:2627-37.

63. Allen-Scott LK, Hatfield JM, McIntyre L. A scoping review of unintended harm associated with public health interventions: towards a typology and an understanding of underlying factors. Int. J. Public Health. Birkhauser Verlag AG; 2014. p. 3-14.

64. Marí-Dell'Olmo M, Novoa AM, Camprubí L, Peralta A, Vásquez-Vera H, Bosch J, et al. Housing policies and health inequalities. Int I Heal Serv. 2017;47:207-32.

65. O'Kane G. What is the real cost of our food? Implications for the environment, society and public health nutrition. Public Health Nutr. Cambridge University Press. 2012;15:268-76.

66. Lietaert M. Cohousing's relevance to degrowth theories. J Clean Prod. 2010;18:576-80.

67. Churchill LR. The United States health care system under managed care: how the commodification of health care distorts ethics and threatens equity. Heal. Care Anal. Springer; 1999. p. 393-411.

\section{Publisher's Note}

Springer Nature remains neutral with regard to jurisdictional claims in published maps and institutional affiliations. 